\title{
THE ECONOMIC FUNCTION OF THE COMMON LAW
}

A widespread attack upon the legal system is one of the marked intellectual movements of the twentieth century. Isolated criticisms of the law emanating from many sources have recently mingled in a sullen stream of discontent that has radiated profound distrust of the law throughout every class of society. Not only have legislators, sociologists, and students in the field of applied science arraigned the law in learned indictments, but even men on the street and soap-box philosophers find popular favor in flaying the once sacrosant legal system. The success of these attacks is proof enough that reverence for the law has vanished; that charges against law may no longer be dismissed as lèse majesté, but must be answered upon their merits. The counsel now retained to defend the law must justify its right to exist by proving that it performs a social function. It is not the purpose of this article to discuss all the social functions of law, but only those that have a vital bearing upon our economic institutions. In thus considering the economic aspect of law it is proposed, first, to show the reasons for the prevalent opposition to law; secondly, to defend the law against this opposition by calling attention to the economic function of law; and thirdly, to reconcile the attack and defense in order to preserve the beneficial features of the economic function of law without turning a deaf ear to the need for reform.

The criticism of law did not develop for the first time in the twentieth century. In fact, a historian would probably search in vain for the exact date upon which the present discontent began. There is the striking evidence of the reformation of the common law by the law merchant and the courts of equity to prove that various causes of dissatisfaction with our legal system have been always with us. It remains true, however, that we have just come through a decade in which criticism of the law has played a larger rôle in the development of thought than it has played in many a previous decade. We have lived to see the scientific culture subdue the field of law and take it out of the realm of sentiment, belief, 
and superstition. We witness the day when we are not afraid to tear the curtain from the inner shrine of law and test its most sacred premises by the standards of the scientific laboratory. For the first time in the memory of living men lawyers have been jolted out of their century-old complacency and judges have been aroused by the rising tide of public opinion. For the first time in its whole history law may fairly be said to be on the defensive.

From out the minutiae of charges that are flung against the legal system one main indictment seems to emerge. This indictment alleges that law is conservative and that conservatism is an evil. In making this particular attack one must carefully distinguish between two vitally different kinds of law, namely, common law and statute law. It is clear that the statute law which changes at the will of the legislature is not conservative. It offers no obstruction to progress. If law can make men virtuous and happy, if statutes can create wealth and cure diseases, the legislature could bring about the social millennium. In fact, the annual flood of new statutes is a curse of our legal system. Even while indicting law in general for its conservatism, we inveigh against statutes because of their unstable character. ${ }^{\text {. The common law }}$ must therefore be singled out as the particular culprit that is responsible for the maintenance of the traditional element in our legal system. $^{2}$

So antagonistic are the two kinds of law that one is the natural opponent of the other. The forces hostile to the static basis of the common law can use the legislative power to demolish the law that is built upon precedents. The reader may then well wonder why a common law which is so easily disposed of by statutes is an obstacle to legal progress. As a matter of fact, it is hard to kill the 107-8.

${ }^{2} C f$. William D. Parkinson, "The Rain of Law," Atlantic Monthly, cxiv (rgr4),

${ }^{2}$ The common law, however, is not the only stable element in our legal system; the fact that the written constitutions of the various states of the Union and the Constitution of the United States nullify any statute which is contradictory to their letter and spirit has subjected these fundamental organs of government to the same criticism that has been directed against the common law. A detailed consideration of the basis of the attack against the Constitution on the ground of conservatism, and the defense against this charge, furnish the material for another article. 
common law by statutes. Even though a statute decreeing the execution of the common law is drafted and passed, the common law, like Banquo's ghost, will not down, but lingers on and makes its presence felt in unsuspected places. Our legal system allows the common law to exercise no inconsiderable degree of control over statutes; only those statutes which clearly and unmistakably conflict with the common law overthrow the common law, and even such unequivocal statutes are interpreted and defined by common-law courts in accordance with common-law principles. Thus in cases of doubtful or ambiguous statutes the common law remains master, and in every case it is the matrix in which the statute law is set. If the statute law fails to cover all of a legal subject, the common law supplies the omission; and when new classes of cases arise that are not governed by statute, they fall at once under the jurisdiction of the common law. Thus the common law is after all a very troublesome opponent to those who want to break away from custom and tradition.

\section{THE REASONS FOR THE ATTACK UPON THE COMMON LAW}

The fundamental reason for the attack upon the common law is to be found in the rapid economic development of America as contrasted with the relatively slow rate of change in the common law. Not only has American industrial revolution proceeded at a rate that surpasses all previous records of change, but the common law has been held back by a load of inherited tendencies which prevented it from adapting itself to American conditions. A brief account of the fundamental factors affecting the development of the American common law on the one hand and American economic conditions on the other hand will tell the story of the existing opposition to law.

The English common law was one of the invisible imports brought over in the "Mayflower" by our Pilgrim Fathers. Consequently we had a fully developed legal system from the very beginning of our Colonial history. The early common law of America was not the creation of any formal law-making body, such as the Continental Congress, nor was it the outgrowth of peculiarly 
American conditions; it was simply a part of the habits and traditions which Englishmen carried with them into the wilderness of the New World. So deeply rooted as a part of their fundamental assumptions was this English common law that our forefathers naïvely proclaimed that they found evidences of this English legal system in the soil of Massachusetts, and they instinctively discovered that titles to the Indian hunting-grounds were transferred by the same procedure as English freeholds. Since the theory of the common law is that a decision of a case merely makes explicit what has always been implicitly the law of the land, the introduction of the common law into America operated retroactively to vest a fee-simple estate in the Indians from whom the colonists could acquire titles by following appropriate English rules. During the early history of this country the legal system was thus regarded as invested with the immutability of the physical qualities of the soil, and by the Declaration of Independence the colonists stated in express words their dependence on the absolute and unvarying laws of property and contract that belonged to the natural order of things.

During the first century of this Republic we were content to leave our legal system alone. The problems of assimilating an undeveloped continent to the machine culture were quite enough to occupy our exclusive attention. As long as the frontier remained, the homesteads in the West and the prospects of striking ore and mineral wealth acted as safety valves for any discontent that might otherwise have reached the foundations of our social order. When all the store of natural wealth had been pre-empted and the fever of the gold rush and land speculation had begun to subside, knowledge of the limitation of our physical resources began to force itself on us. While the ultimate end of our coal supply, our forests, and our iron deposits was yet far away, the very fact that their content was capable of being measured in approximate terms aroused us to the realization that there was not room enough for all and that the niggardliness of nature would compel a struggle between the social classes for the very means of existence. The beginning of the end of reckless expansion was reflected on one side in a demand for a restriction of immigration and in a cry for the 
conservation of natural resources in order that the pressure between population and natural resources might be alleviated. It was reflected on another side by a cry for justice in the distribution of wealth. As long as our resources were apparently unlimited, more was to be gained by exploitative production than by spending time and effort on social justice. After the easy opportunity to exploit natural resources became a thing of the past, the emphasis shifted. With the land all parceled out, the open frontier closed, individuals found that an increase in their wealth could be made by forcing a change in property lines as well as by an increase in production.

As a stage of diminishing returns began in producing wealth, a stage of increasing returns began in the results attained from attacking the system of distributing wealth. The harder the struggle to earn a living from a common spoliation of lands and mines the closer became the contact and the more hostile the interests of the groups engaged in production. As the bargaining struggle grew in intensity, it shook the fundamental institutions which prescribed the rules for the bargaining struggle. Agitation for the single tax, for a minimum wage, for eight-hour legislation, and for a great variety of factory laws indicated that many were not satisfied with the decisions of the common law in adjusting the rights of conflicting groups; while the popular campaigns for the initiative and referendum and the recall of judges served notice upon the legal profession that there was dissatisfaction with the processes by which the common law reached these results. Thus we witness a sudden rush of forces that seek to establish an equilibrium between the old common law and the new industrial conditions by raising the common law to the level of modern attainment. As the barrier that stands in the way of this process of adjustment is conceived to be the unchanging character of the common law, the forces making for change have been directed against it.

The indictment against the conservative element in law is drawn for the most part by groups which were adversely affected by the changed economic conditions. The various forces and motives behind the opposition to a stable legal system may be roughly divided into eight classes. The list is not complete and 
the classes that are enumerated are by no means separate and distinct. The following classification is at best a mere suggestion of some of the prevailing forms of the innumerable permutations and combinations of criticisms directed against the common law by a countless number of individuals.

The first force opposing conservatism has arisen out of the selfinterest of the industrial classes whose importance has increased since the industrial revolution. The common law that administered to the needs of the apprentice, who worked and lived in the home of his master, had little conception of the needs of the laborer who worked in a factory with a thousand fellow-servants. The common law afforded scant protection to the laboring class against the forces of the new technique which threatened to undermine the health, morals, and standards of living of factory workers. The agitation for the social culminative legislation just referred to ${ }^{\mathrm{x}}$ was an expression of the self-interest of the working class. The interference with the common-law freedom of contract was necessary to secure real freedom of contract; the limitation of the right of each laborer to make the most profitable bargain was the only alternative to the degradation of all laborers by cutthroat competition.

A second charge against the fixity of the common law is made by those who believe that the stability of the common law lends itself to selfish manipulation by the propertied classes. It is asserted that the early common law-either because it was consciously promulgated by a feudal aristocracy to serve vested privilege or because it crystallized at a time when the safety of property was the chief concern of the state-was especially devised to secure the domination of property rights. It is further alleged that this same reverence for property carried over into a later day by the method of following precedents has impregnated judges and the whole system of common law with an undue regard for the interests of property-owners. Thus at the very time when larger emphasis is being placed upon the human values of health, morals, and happiness, it is said that bloated bondholders, with simulated piety for the sanctity of law, use this tender sympathy of the common law for property as an instrument to coin health, morals, and even human life into property value.

× Supra, p. I7I. 
A third protest against the stability of the common law springs from those who want cases to be decided by an appeal to the emotions. Sentiment demands that the injured workman in his mangled flesh and blood win over the pale and soulless corporation, regardless of the facts attending the injury. Compassion for human suffering and poverty pleads for the triumph of the poor over the rich; sympathy for the downtrodden urges that a struggling workman with a wife and six children should be given the. verdict against the bloated corporation magnate. Pity for the under dog calls upon us to aid the helpless criminal in his fight against the fearful odds of the whole state arrayed against him. The widow's tears, the orphan's cries, the repentant offender's anguished look, point to the easiest way of deciding a case. Thus would our emotions guide us. The skill with which the feminine defendant plays the rôle of injured innocence, the personal qualities of witnesses, the number of children dependent upon the injured plaintiff, the political views of the parties, the looks and bearing of witnesses, and countless other personal matters would be the decisive factors in a lawsuit. These are in fact so often the decisive factors in jury trials today that the most successful trial lawyer is the man who is an artist in playing upon emotions. The common law limits the power of the jury to decide cases by requiring a certain percentage of hard, cold facts as a prerequisite to submission to a jury, and consequently it incurs the enmity of the persons who would profit by the common prejudices and sympathies of men.

A fourth force seeking to break the rigid mold of the common law is also founded upon a dissatisfaction with the standards set by the common law in the decision of cases, but it proposes to substitute new standards for the old instead of leaving us to be tossed about by the changing emotions of juries without the chart or compass of legal standards. The new standards which would replace the old principles of the common law would be derived from a study of the special problems that have accompanied modern industrial change and the unique conditions in America. It is insisted that a greater degree of justice can be secured by trying a man under laws based on the facts of his own age and environment than by trying him under a system of laws developed under a different 
condition of society. Especially is there a need of framing new standards of law when rapid industrial change has produced a situation altogether different from any hitherto known.

A fifth factor moving toward the changing of the common law has been the social psychology of the times. Many people in this age demand change for its own sake. They are impatient with stable institutions because they are stable. There is a restlessness in the air fostered by the progress of mechanical inventions, the industrial expansion of a new continent, and the speeding up of our whole industrial system under the excitement of rapid growth. The law of the ninteenth-century model is regarded as one of a kind with I850 hoopskirts and I905 automobiles, and it is urged that we change our laws as fast as fashions, class interests, and political parties change. The conservatism of the common law is not only an evil per se in its effect upon law, but it sets a bad example for all other institutions besides law. The imitation of the common law in the business world stifles the progressive spirit and encourages us to go in the same old rut year after year without seeking to initiate any change.

A sixth count in the indictment is founded on administrative defects in the machinery of the common-law courts. The complaint against "the law's delay" has been made by almost every party to a lawsuit before and since the time of Hamlet. The slow grinding of the mills of justice becomes even more painfully obvious when it is contrasted with the accelerated movement of everything else. Many plain folk are convinced that this slowness and complexity of form is purposely designed to ensnare the poor and ignorant, and so when a case is decided after long delay the people are convinced that it was a plot to frame up some technicality. Because of the inherited seals, oaths, and solemnity - the formal and antiquated phraseology - of judicial procedure, still other simple folk are led to associate all law with the criminal law and to look askance at any man who has business with a lawyer. The expenses of litigation are also increased by keeping up forms that have outlived their usefulness. These various sore spots have prompted many a man to condemn the very alpha and omega of law. 
A seventh force that seeks to shatter the conservatism of law is scientific progress. It is characteristic of all research investigation that it is the work of specialists, that the contributions made to science are perfected in laboratories and accepted by the leaders in the various fields of thought long before they are accepted by the masses. Since the common law, however, represents only the average common sense of the masses and not the specialized common sense of the leaders, it refuses to accept the fruits of scientific endeavor until the results have percolated through all the classes of society, and it has consequently upheld obsolete theories of government, punished criminals on a theory of retributive justice, which psychologists and criminologists have condemned as barbaric, approved of medical treatment which doctors of good standing would consider suicidal, and framed theories of human conduct which threw a crushing weight of personal responsibility upon the socially downtrodden, with the result that mankind has lost many of the benefits of the early adoption of scientific discoveries.

The final count in the indictment of the common law is a direct attack upon its basis. Modern sociological studies have clearly demonstrated that the natural order is a myth, that the abstractions of human nature and common sense are fairy tales, and that there are no absolutely fixed fundamental rights. The pretension that the common law is immutable and that courts do not make new common law, but merely point out a legal fact that was present all the time, like the concealed figure in a picture puzzle, obscures the fact that the social order is a constantly changing thing. When new wants arise that are not provided for by the existing common law, why not recognize the fact that new laws must be made instead of torturing old rules to meet the new situation? The common law is not omnipotent; the common law of the time of Edward III sheds little light upon the question of the liability of employers for failure to fence dangerous machinery, or upon the question of the liability of aëronauts in an action of trespass.

To summarize our indictment, all the charges are based upon the relatively unchanging character of the common law. The common law has been marking time, while the fundamental nature of 
our industrial life and the basic premises of our thought have been marching forward: (I) in worshiping at the shrine of our ancestors the common law has ignored the industrial revolution and the rise of social classes, and has forced a yoke of slavery upon the laboring classes in the name of freedom of contract and the protection of life, liberty, and property; (2) in obeying precedent the common law has conferred wealth and power upon those "that hath", while from those who have not worldly goods it has taken away health, honor, and happiness, also; (3) for the sake of maintaining a logical consistency with the past it has turned a deaf ear to the anguished appeals of widows and orphans and has ruthlessly brushed aside as irrelevant the most tender human relationships; (4) in its servility to custom the common law has judged present litigants by archaic standards and hence sets a trap to catch those who are not schooled in the standards of the Middle Ages; (5) in its obstinate reverence for the wig and ermine it has refused to follow the lead of millinery and adopt new styles to please the modern desire for change; (6) in order to maintain its traditional select position, it has refused to scrap its obsolescent machinery or to discharge its host of feudal retainers, and it has thereby withheld the benefits of litigation from the poor and weakened their respect for law and order; ( 7 ) in following the rule-of-thumb methods of the Middle Ages the common law has so often failed to heed the teachings of modern science in the fields of government, psychology, medicine, and sociology that it has become a museum of exploded theories. Finally, to cap the climax to all this mummery, the whole system of common law has been put together on an utterly fictitious theory. These are the grave offenses of which the common law stands charged, and they are all based upon one major premise: "The common law is an iron standard which never changes. It received its character from the Middle Ages, which conceived of law in absolute and unchanging terms. Immutability has been its dominant note ever since, and this immutability is the source of all its evils."

The number and gravity of these charges put a heavy burden of proof upon the common law. It must now justify in no uncertain terms its very right to exist. The fundamental assumptions which 
justify the law as a matter of course to the bench and bar must now be exhibited to the public to allay the angry murmuring. The philosophy that runs through thousands of learned opinions must be distilled from the concrete applications in particular cases in order that the masses may understand the reasons that justify the common law. Even though this statement of legal doctrine be condensed and shorn of its concrete applications, even though the defense of the common law be a generalization without the vivid cumulative force that is added by the knowledge of specific cases, it is better probably for the layman to see through a smoked glass darkly than not to see at all.

II. REASONS WHY THE BENEFITS OF THE STABLE COMMON LAW ARE NOT BETTER UNDERSTOOD

The common law must plead guilty to a charge of conservatism, but its apologists insist that the conservatism that results from following precedents is not an unmixed evil. The charges just made $^{\mathrm{r}}$ against the legal system are mainly true, but they tell only part of the story. The final judgment in the case of the people versus the common law must be deferred until the defense has had an opportunity to display the bright side of conservatism.

Since the attack upon the common law is a summation of a great many cases of individual hardship that have resulted from an unswerving devotion to ancient custom, the defense of the common law should likewise consist of an accumulation of cases of individual gain through the maintenance of settled rules of law. There is one striking difference, however, between the attack and the defense. The wounds inflicted by the common law strike particular individuals directly, while the blessings conferred by the common law flow from the general social reservoir that is accepted by the multitude as a gift from Heaven. The disadvantages of the common law are measured by a direct pecuniary loss or by a definite prohibition of an attempted act. The advantages of the common law are unapportioned; they benefit the individual only through the medium of certain fundamental institutions, which are usually

I Supra, pp. I72-I 77 . 
accepted as a part of our physical environment. The effect of the common law in checking objective action is easily seen and criticized, but the effect of the common law in touching the springs of human action is not easily seen and is consequently not generally commended. The urgent need of making a defense for the common law arises out of the fact that arguments in its favor do not lie upon the surface and hence may be overlooked.

The common law thus has two sides, one of which is easily seen and the other of which is often obscured. The side that is easily seen is the individual hardship thrust upon the losing party to a suit; the side that is not easily seen is the social consequence of the decision in a particular case. What is not easily seen is that a judicial decision does not spend its force upon the actual litigants, but that it extends to a wide social area, that the whole business world relies upon the decisions of concrete cases to furnish a guide to future action, and that, in consequence, if the concrete cases are decided upon the personal histories of the parties to the case without reference to any external standards, business men are forced to leap in the dark. Thus the side of the common law that is obscured from view is the necessity of developing logical consistency at the expense of a certain amount of hardship in individual cases, so that the law will be, not a mere lottery, but a basis for careful calculation.

If it were possible to reduce subjective states of mind to a definite objective scale, then it might be feasible to consider the personal idiosyncracies of the litigants. Although states of mind are just as tangible and real, if not more so, than anything in the physical world, the difficulty of measuring their content by an objective scale prevents their adoption as a social norm of conduct. Chief Justice Brian, a famous jurist of mediaeval England, declared that the devil himself knoweth not the thought of man. The psychological laboratory has made considerable progress since then, but a federal judge ${ }^{\mathrm{I}}$ in the year I9I 7 is still forced to concede that "science has not yet found a process by which to open the skull of a crooked lawyer to determine the mental processes of the brain."

I Newspaper report of statement of Judge Landis during an informal hearing before the federal court in Chicago. 
The only alternative to allowing men to be the judges of their own cases is to devise some objective means of evaluating their conduct. Following a definite legal path is the only method that prevents an unrestricted reign of personal prejudices and emotions.

Thus far the writer has attempted to show how the common law fell from grace and the reasons for the present attack upon it. He has sought to explain further why the value of a stable common law is not readily appreciated. The rest of this section will be devoted to a discussion of the benefits of the common law that have been labeled the "economic function of the common law."

\section{THE ECONOMIC FUNCTION OF THE COMMON LAW}

The stability of the common law aids the present competitive organization of society in two fundamental ways: First, it guarantees that the legal factors in a business situation will remain constant during the period of carrying out any given undertaking, and, secondly, it serves clear notice upon business men as to what will be the legal consequences of any proposed action. These services may seem trivial at first blush; but a little examination will show that they furnish the basis for our present industrial mechanism, with its wonderful specialization of parts and powerful motive force. It is almost needless to add that the specialization and intensity of effort thus made possible by the common law has enormously increased the efficiency of production. The method by which this social gain has been realized through a conservative legal system is certainly worth investigating.

The first economic function of the common law closely resembles the function of money as a standard of deferred payments. It assures men who are about to make contracts or buy property that the same legal conditions which existed at the time the contract or sale was made will continue to exist throughout the whole period of time in which the bargaining parties are interested. The value of fixed legal standards can be shown by reference to their service, first, in preserving property rights, and, secondly, in maintaining the obligation of contracts.

The economic importance of the stability of property rights.-The institution of private property with all its attendant benefits is 
directly dependent upon an unchanging common law. ${ }^{\mathrm{I}}$ Private property consists of a bundle of rights whose size is increased or diminished by a change in the course of judicial decisions. The common notion that the ownership of land or goods is determined by physical laws irrespective of the views or opinions of courts is the result of a profound ignorance of the character of property rights. As a matter of fact the right of ownership in the most tangible object of property may slip through one's fingers or evaporate overnight as a result of a judgment in a case not directly involving the property it so mysteriously affects. While the actual goods themselves do not take wings, the right to control those goods may thus suddenly be transferred to another.

The methods by which private-property rights are affected by the legal system are legion. Seizure of property rights in exceptional cases is allowed even by the conservative common law. The most obvious is the appropriation of the whole right of ownership by the state or a public-utility corporation under the right of eminent domain. Since just compensation is made for property thus taken, the person whose property is seized has no financial grievance, but his absolute right of dominion over an object for which he may have formed a sentimental attachment is no less seriously interfered with. ${ }^{2}$ Hardly less direct than this seizure under the right of eminent domain is the seizure of land for non-payment of taxes. Still the point has not been reached where property is taken without an equivalent being paid; for the landowner has had full opportunity to reclaim his land by paying the taxes. While an unchanging legal system thus allows a forfeiture of private rights in the public interest, it normally provides for compensation, and hence does not disturb pecuniary values or increase the hazards of trade.

The stable common law, however, goes farther and even recognizes a method by which a man's entire interest in goods may be destroyed without any payment in return. The dynamiting of

${ }^{x}$ For a full statement of the benefits of private property see W. H. Hamilton, Current Economic Problems (University of Chicago Press, 19I5), pp. 666-68. ("My Apology," by P. Property.)

${ }^{2}$ In the present war private dominion over property may be superseded by government control in a great many instances. Cf. Moulton, "Industrial Conscription," Journal of Political Economy, XXV (I9I7), 9I7. 
buildings to stop the progress of a great fire, the killing of diseased stock, the destruction of gambling devices, the tearing down of dangerous structures, are all examples of confiscation of property. The legitimate exercise of this extraordinary power is always confined to cases where important public interests are threatened by a relatively minor individual interest, and the cases themselves usually arise out of emergencies created by great fires or epidemics. Where the impairment of the stability of some property rights thus affords protection to property of far greater value than that destroyed, or where the destruction of property is necessary to safeguard health, morals, or life, the sacrifice of property is clearly justified under any legal system.

Thus far we have mentioned only the phases of the method of seizing property that are incidental to the performance of very useful, if not vital, social functions. It may be that even these-the right of eminent domain and the police power-work some injustice, but it is trivial compared to the harm that would be occasioned by capricious courts. Where the open and direct appropriation of rights of ownership with compensation slays its tens, the secret undermining by court decisions would slay its thousands if given the opportunity. To one case where the whole property interest is commandeered for a public purpose, there are a great many where it is more or less secretly nibbled away for no purpose at all. It is, moreover, the seizure of property that comes as a by-product of changing laws that has the most harmful effect on the pecuniary system. The destruction of property rights without notice and without compensation, whether upon a large scale or upon a small scale, cannot fail to increase the risks of doing business, and discourage men from undertaking new enterprises.

The harm of changing laws consists of the destruction of vested rights. The value of property rights in land or goods is dependent upon a large number of legal decisions affecting the manner of using the property, not to mention the decisions upon which the chain of title depends. A settled line of decisions may restrain any one man from establishing a tannery in the midst of a residence section. Relying upon these decisions, people invest in land in that neighborhood and pay the price which land free from the noises and odors 
of a tannery would be worth. If some judge now decides that ideal justice to a very worthy tanner demands the reversal of the old line of cases, part of the property of every other landowner in the neighborhood would be immediately confiscated. Thus any change in the decisions regulating the use to which land may be put, whether it be the prohibition of its use for saloon purposes, the regulation of the price of service of a heavy investment of fixed capital that has been sunk into it, the limitation of the height of buildings that may be erected upon it, or the control of the character of the neighborhood in which it is located, produces a corresponding change in the value of the land. The value of property thus expands and contracts with the changes in laws which seem at first to have little connection with property rights. ${ }^{\mathrm{I}}$

The most deadly menace to the security of property values, however, fortunately has not yet made its appearance on any extensive scale, but its possibility is vividly suggested by the proposals of some of the opponents of a stable legal system. If the tinkering with ancient custom proceeded to the extent of changing the formal requisites of a deed, the capacity of parties to make contracts, the length of the period of the statute of limitations, and many other seemingly minor appendages of our legal system, the effect would be to break an ancient link in many chains of title and thereby change the ownership of a vast amount of property arbitrarily. ${ }^{2} \mathrm{~A}$ sudden reversal of a long line of decisions by a common-law judge would have this retroactive effect because of the theory that the very latest decision announces what has always been the law. So deeply is this fictitious theory imbedded in the common law that

I The possibility of a loss of property rights through a change in legal decisions will increase the risk of doing business only when the change in the law comes out of a clear sky without any preceding social changes. Where property values decline because of the gradual influx of manufacturing plants, or because of a slow change in social conditions due to any one of a great variety of reasons, a decision which would recognize this changed situation should not be blamed for the loss that has resulted.

2 There is one limitation on the extent of the retroactive operation of a decision according to the principle of res judicata; a case once decided by a court can never be tried over again by the same parties. Hence no change in decisions can overturn an identical case previously decided. The principle of res judicata, however, does not prevent new parties from suing to get the benefit of the reversal of precedents. 
it could be eradicated only with the greatest difficulty. While some courts have already discarded the doctrine that common-law decisions are only evidence of an ideal and immutable system of natural law, many other courts still retain it and will continue to do so for many years. Only by demolishing the common law, root and branch, a proceeding that would certainly destroy property rights on a vast scale, could we completely rid ourselves of the retroactive element in the common law. We must therefore accept the situation as we find it and count the cost of reversing decisions affecting the mode of transferring title to property.

The cost of confiscating property can be computed in definite terms. Whether the confiscation be the high-handed act of a de acto government, or the by-product of changing the common law, society must eventually pay the bill. The first loss falls upon some individual whom blind luck has selected to be the victim. This unfortunate sees the property which he had schemed and toiled to obtain and upon the expectation of which he had adjusted his standard of living, incurred obligations, and made plans for his children and grandchildren, suddenly torn from his grasp by a decision of court to the effect that his title is void for want of some requirement hitherto considered unnecessary. The sense of injustice which this deprivation arouses in the heart of the loser is kindled to highest pitch by the knowledge that this property will probably go to someone who neither deserved nor expected such a windfall. The subsequent career of the victim of unstable laws is overshadowed by the bitter lesson that thrift and foresight did not pay him and that his hard work earned no sure reward. This story is repeated with greater or less emotional stress whenever the private property of any man is either consumed or whittled away by an unexpected change in law. This disastrous effect upon the morale of the individual is intensified by its communication to others. Other men are bound to draw the moral from the lesson, and like a contagion the fever of speculation sweeps through the country.

The sudden reversal of fortunes by any capricious circumstance is bound to discourage thrift and encourage profligate living, and the shifting of property lines by court decision is no exception to 
the general rule. All the members of society learn from the smarting of the individual who has suffered what to avoid in the future, and the certainty that some individuals have suffered because legal standards have been freely overturned in the past will teach everyone to regard the future as an uncertain quantity. Consequently the individual who is about to decide between the present consumption of his wealth and saving for the future will decide to eat, drink, and be merry today rather than deny himself for a very uncertain tomorrow. Moreover, the increase in wasteful consumption has an unfortunate reaction upon production. When the rewards of abstinence are found to turn to ashes, the winning of wealth by patient plodding will be abandoned in favor of a getrich-quick philosophy. For just as a stable legal system encourages men to base their hopes of wealth-getting upon scientific calculation, so an unstable legal system of the frontier type encourages a reckless gambling spirit that prompts the individual to seek his fortune by despoiling others without making any net addition to the wealth of society. Thus the initial uncertainty due to changing laws is greatly accentuated by the breakdown of productive habits, and the shifting of many men from the ranks of productive laborers to the ranks of those who live by preying upon productive laborers. If the reader doubts this blighting effect of unstable laws upon thrift and industry, he need but turn his eyes to Mexico and see enacted there the peril of a changing legal system, or read in the confiscation of the crown lands of Russia the story of demoralization attending a violent revolution in property rights. ${ }^{\mathrm{I}}$

The gain of a stable common law, or the cost of unstable laws, has not yet been translated from the subjective cost to objective fact. The psychological effect has not yet been registered in our pecuniary system. The connection between the security of property and the efficiency of industrial society is none the less vital because it arises from the mental attitudes of men. In a system of private-exchange co-operation which depends upon the volun-

I During the Diaz régime, when stable legal conditions were maintained, large amounts of foreign capital were invested in Mexico, but during the shifting state of affairs that has followed Diaz, not only has there been an abrupt falling off in the influx of new capital, but doubtless much of the capital already invested has been withdrawn. 
tary action of individuals to furnish the motive power, states of mind are of the highest importance. Freedom from worry over a threatened loss of all one's worldly goods is necessary to secure the undivided energy and attention of labor. The assurance that property rights in great investments of fixed capital will be kept inviolate is essential before men will make the mental resolve to transfer their goods from the monetary form, that can be easily protected from legal attachment, into a form that can be easily seized. The psychological determination to save for the future is a prerequisite to capital accumulation, to a wise conservation of natural resources, and to a careful development of earning capacity on the part of laborers. These are all states of mind, but they are directly responsible for the upkeep of the land, labor, and capital that furnish the sinews for war and for peace. ${ }^{x}$

Economic importance of the stability of contract rights.-Stability of law is no less valuable in the case of contract than in property rights. Practically all of the arguments made in favor of securing the ownership of goods apply here with almost equal force. Business men stake large sums of money and large property interests upon the faithful performance of contracts, and they implicitly rely upon a return of an equivalent at the end of the contract period. Let the laws of contract vary so that men originally bound under contract could later escape, and mankind would be astounded at the remarkable change that would come over the business world.

In an age of specialization the importance of stable laws of contract cannot be overestimated. The relationships between all the complex parts of our modern-exchange society are fixed by contracts, and the duty of each specialist is thereby defined so that every man knows what part he must do himself and what part he can expect others to do. The success of our system of co-operation depends upon the certainty with which one man can rely upon the co-operation of another to do his part, and if changing laws of contract permit one man to slip out of a binding obligation the work

I A feeling of uncertainty caused by a situation very similar to that of a changing legal system - the proposal to change the standard of value by adopting bimetallismled to the return of $\$ 300,000,000$ of American securities by foreigners during 1893 and the early part of 1894 and perhaps also checked the new purchases of our securities that normally have been made.-Report of the Indianapolis Monetary Commission (1898), p. 438, cited in Moulton, Money and Banking (I916), p. 234. 
of every other man dependent upon the defaulting worker is hindered. Since the advantages of large-scale production cannot be obtained by one man alone, the conditions enabling many men to combine their efforts must be made easy and safe. The entrepreneur will not undertake even a small business unless he can exercise the power of coercion of the obligation of contracts to compel landlords, laborers, and capitalists to furnish their services. Similarly one kind of labor looks to the promise of another kind of labor, and one business house relies upon a contract with the producer of raw materials to furnish the means of production and turns to those who have contracted for the finished products to take the output when it is ready. A commercial house is dependent upon contracts made with banks, railroads, and commission houses to keep it in touch with the arteries of trade. In short the great degree to which interdependence and co-operation have been carried in the business world has been made possible by unvarying laws of contract. If these laws were free to change at the dictates of sentiment, society would inevitably relapse into the handicraft stage, because, if it could not have the power of contractual obligation to enforce the services of the neighbors upon which it depended for its very means of subsistence, each household would have to be self-sufficient. ${ }^{x}$

Credit is founded upon a stable legal system.-The value of unchanging laws is reflected in the present economic order in many angles. The whole mechanism of credit is built upon stable laws of contract and property. Not only is the psychology of thrift and calculation necessary for the development of a credit economy, but the giving of credit directly rests upon the assurance that contract and property rights will not vary during the period for which credit is extended. Credit is advanced chiefly upon reliance of the debtor's title to goods and upon the success of the debtor's business and his reputation for sound business judgment. If arbitrary legal forces suddenly divest the debtor of title to goods at one blow, the whole basis of credit is shattered. The goods which are relied upon to pay the debt are suddenly thrown out of reach, the elements of

× The importance of stable laws of contract is recognized by the Constitution of the United States, art. i, sec. Io; this nullifies statutes which would change the obligation of contracts, but cannot prevent the impairment of contracts that might be brought about by court decisions. 
sound business judgment based upon rational calculation are rendered worthless, and business success, which is the product of sound business judgment, is likewise destroyed. Credit depends upon economic morale, and that is largely bolstered up by the security of property and contract rights. There can be little doubt, therefore, that the whole credit mechanism of our society would snap with the first suspicion of any wide confiscation of property, whether it was brought about by sheer robbery or through the more polite medium of the reversal of precedents. Thus the effect of unstable laws would be to put us back into the dark ages of industry.

The economic importance of certainty as to what the law is.The first effect of the stability of the common law is to maintain the same legal conditions throughout a given period. The second effect of stability is to throw a searchlight upon the common law so that every layman can understand it. Common-law decisions leave tracks in the legal wilderness. If these tracks establish a beaten trail by the constant traveling over the same route, the public has no difficulty in following, just as by constant repetition an old principle wears a pathway in our mental processes, so that obedience to it becomes instinctive.

The necessity for a definite knowledge of what is legal becomes increasingly important with the growing interdependence of modern industrial society. Even as rational economic judgment depends upon the tagging of every commodity with a definite price, so it also depends upon the tagging of every act with a definite legal value. The complexity of our present social relationships emphasizes the fact that the social rights and duties of individuals are not prescribed by physical laws. There are so many factors in the physical chain of causation that might be charged with entire responsibility for the consequences of a given act that all responsibility would be continually shifted unless some well-established law definitely discriminated between the various elements, imputing blame to some and releasing others from all liability. Neither the physical character of the act nor the intent wholly governs to fix the legal judgment. The intentional killing of a human being by another human being is in one case murder in the first degree, in another case manslaughter, in another case justifiable homicide, in another case the 
execution of a duty imposed by law against a condemned criminal or a public enemy. In all of these cases the physical act may have been the same and the evil intent the same, yet the legal consequences that attach differ widely. Similarly an individual must pay damages for some acts of his that are prompted by benevolent motives; he may be relieved of all blame in other cases where he acted with most vicious motives. There is no certain standard that can be instinctively applied. The individual must be able to look to the valuation placed on his acts by the wider social standard afforded by a stable legal system.

There is all the more need for definite legal evaluation of conduct because of the great distance both in space and time which separates the original act from its ultimate effects. The events started in motion by a single volitional act are so far-reaching, they communicate with so many phases of human life, that no man can predict with absolute certainty what will be the end. A defectively constructed engine may ultimately cause the death of a score of workmen; a hidden flaw in a steel rail may cause a train-wreck. How far down the sequence of events will responsibility be carried? When may a man be assured that he will not be brought face to face with the forgotten consequences of an act of long ago? Here is shown the definite need for a standard of legal values which will clearly set forth the final verdict that will be passed in the future upon an act of today.

Certainty as to what is legal is thus necessary to secure the incentives for progressive action upon which the movement of our pecuniary society depends. The fear of unforeseeable penalties will depress individual initiative and therefore stop the dynamos that furnish energy to move the wheels of our industrial mechanism. Unless business men can estimate the costs they will not venture upon new enterprises. They hesitate to assume large contingent liabilities, which may be only clouds and which are yet always potentially dangerous. ${ }^{I}$ They insist upon knowing what will happen if they take a certain step, how it will be appraised by law, what the moral reaction of the community will be, and what it will cost them

I The attractiveness of the corporation as a form of business enterprise has been largely due to the fact that it substituted a definite, limited liability for the uncertain and unlimited liability of the partnership. 
in money. Upon these criteria they base their judgments, and without them they would be at sea without chart or compass. The results of action may be realized in the far-distant future or at a distant place, but the business man demands that his liability for those results be fixed here and now. He looks to stable legal standards to furnish him with this information. ${ }^{\mathrm{I}}$

A definite system of legal values thus stimulates the kind of activity which society deems desirable. It also depresses another kind of activity which society deems undesirable. Regardless of one's theory of the cause of criminality, it can hardly be denied that the rigorous enforcement of a definite set of penalties prescribed by the criminal law has a deterrent effect upon crime. Even though criminals be the products of bad social conditions for which they are not personally responsible, they nevertheless weigh the prospective gains of the crime with the risk of detection and the probability that punishment will be sure and swift. The very definiteness of a harsh legal penalty tends to eliminate perverted activities. To the prisoner who complained of the harshness of the English law which made horse-stealing a capital offense, the judge on the King's Bench replied that men were hanged in England, not because they stole horses, but in order that horses might not be stolen in England. Thus an unchanging criminal law reduces the sum the business world must pay for burglary insurance.

Business men not only look to law to define the consequences of their own activity, but expect the law to furnish the standards with which to measure the conduct of others with whom they have dealings. It is at least as important for entrepreneurs to know upon what terms they can hold others to account as it is for them to understand the nature of their own liability. If business men were bound to ascertain at their peril the secret intentions of their customers with regard to contracts of sale, and if the whimsical notions of every individual who bought goods were allowed to fix the terms of a bargain, there would be very little business transacted. Standards of legal value, however, reduce all of these eccentricities to a common denominator or social norm of conduct which overrides

I Business men prefer a stable legal system which is inherently vicious to an unstable legal system which is otherwise meritorious, because they can insure or make special contracts to avoid objectionable consequences. 
the individual theories of justice or the hidden purpose of a party to a contract. Contracts are made and interpreted, not according to the subjective intent of the parties, but according to the common meaning of their words and actions. The authority of an agent to act for his principal is not determined by the secret instructions that were whispered between the two, but by the interpretation which ordinary men would place upon their outward dealings with each other. Men are not liable for negligence according to their own lights, but according to the social average conduct of a representative citizen under like circumstances. The measure of damages is the pecuniary loss determined by the price mechanism, not the unusual loss which the individual may claim he suffered because of his extreme nervousness, or loss of opportunity not capable of being evaluated on the market. Standards of legal value thus tend to conform in many cases to the community standards or to the ideas and modes of living that pass current throughout the group. Familiar standards are thus set at a level which nearly all can attain, and knowledge of these community habits becomes a part of one's social inheritance.

Convenient business forms are furnished by a stable legal system.The common law has further adapted itself to the needs of commerce by evolving stock forms which have a well-recognized significance in the business world. Where the requirements of commerce have demanded legal instruments that would pass readily from hand to hand, the common law has supplied the need by the use of stereotyped forms, which carry a definite meaning to every layman by virtue of their constant use. When the cumbersome methods of the early law clogged the rapid movement of goods, the customs of the law merchant were made a part of the common law. The necessity of examining the title of the vendor of a chattel was abrogated to the extent of allowing a bona fide purchaser of a bill or note to hold prior parties on the instrument. In many other fields the sharp edges of old legal standards have been worn off by the necessities of trade. The law furnishes blank forms which allow laymen to transfer title to their property without bothering to investigate the legal phraseology necessary to accomplish their purpose. The common law further recognizes de facto rights and 
institutions in order to meet the everyday needs of business men. It is not necessary for shippers to read the charters of a dozen railroads and the corporation statutes of a dozen states before they can safely decide to ship goods across the continent. A man who wants to bid on property at a sheriff's sale need not investigate the ballots which elected the sheriff before he can safely buy. In both cases men are protected in their dealings with corporations and officers who appear before the world with all the semblance of legal authority. The validity of a vast number of business transactions therefore depends, not upon the ultimate facts deposited in some office or not revealed explicitly at all, but upon the average social conception of these ultimate facts. Thus the calculations of entrepreneurs are not upset by hidden perils or by odd or unusual individuals, but they can deal with all on the assumption that they conform to the average type, unless there are special facts to put them on guard. All these things are possible because the common law develops some settled rules until they crystallize into routine forms.

The pecuniary value of stable laws.-In a summary of the economic function of law the gains of a stable legal system, or rather the losses that would accrue from the lack of a stable legal system, can be measured in the standards of the business world. Statements of profit and loss, financial statements, and bank balances comprise the cold logic that sways the judgment of captains of industry. Therefore, in these very terms we shall address them; the ledgers of the pecuniary calculus shall prove our case. That manufacturing costs would mount upward with the decline of specialization carries its own proof. No statistical demonstration is needed to convince us that the greater the element of risk the greater the cost of insurance, or the greater the profits that must be paid to cover the extra hazard. It is wholly evident that even the legal expenses of business would increase proportionately with the uncertainty of law. Yet it can scarcely be doubted that the abolition of stable laws would cause a decline in specialization and an increase in the risks of doing business. The exact cost society would pay for a sentimental administration of justice-each case on its merits - can be computed only when we know to what extent the 
conservatism of law will be uprooted. If the changes were relatively small or tempered to the spirit of the times, the shrinkage in capital values might be correspondingly low; but let the changes be relatively large and made without thought of the social temperament, and the shrinkage in capital values may well exceed the figures of a war appropriation.

The value of a stable legal system to the laboring classes.-The moral of this lesson for the laboring masses is still untold. If the shrinkage in property values resulting from unstable laws were lopped from huge fortunes, if the blow to industry fell chiefly upon the idle rich, the poor would not need to heed this warning. Such, however, is not the case. Situations of uncertainty and wild speculation are the very conditions out of which great fortunes emerge. Large profits go to the few when great wars and crises produce sudden changes in demand, or when a great revolution produces a shifting of property lines. As interest rates shoot upward because of the lessened supply of capital, production is curtailed, and the demand for labor declines. As panic and wild speculation succeed the steady rhythm of industry, factories close down, and with their close go opportunities for the employment of labor. Unemployment increases among the laboring population and actual starvation threatens the submerged tenth. Discontent is stilled by the hopelessness of the situation and by the knowledge that there is no firm hand capable of bringing order out of the chaos. Since the size of families is largest where the opportunities for self-improvement and healthy recreation are the least, it may be that this very despair of ever becoming economically independent, together with the ignorance, shiftlessness, and intemperance that arise from unstable conditions, drives the poor to seek early marriage and large families as the only pleasures within their means, so that the only source of joy in their sodden lives may become the very means of depressing the wages and living conditions of their offspring to even lower levels, and thereby make possible a progressive degradation of the masses, until they sink to the level of the pauperized millions of China and India. Thus, finally, by a long and roundabout process the lesson would be brought home to the common people that stable laws had yielded benefits, although these benefits were formerly concealed in the smooth working of the industrial mechanism. 


\section{RECONCILIATION OF THE ATTACK AND DEFENSE OF THE COMMON LAW}

At the outset of this last section a dilemma presents itself. On the one hand we have seen the common law criticized for holding back progressive movements of great value. To give full faith and credit to this criticism would mean the abolition of stable laws. On the other hand we have seen the advantages of a stable legal system. To give full opportunity for the complete realization of these advantages would mean that the common law would stand still indefinitely. Obviously we must escape the sharp points of the two horns of the dilemma by choosing a middle ground. The first step in that direction may be taken by recognizing that the common law must change to some extent; that the fiction of the absolute immutability of the common law is not true to fact or desirable if it were true. As a matter of fact the common law is changing every day, although the method by which the change is effected may not be generally understood.

The real elasticity of any law, whether it be statute or common law, is concealed from view by the rigidity of its outward form. Lawyers and laymen alike are prone to think that a legal rule conveys definite rights of fixed magnitude throughout all the ages. The man on the street is likely to think of a clause of the Constitution of the United States as an absolute, unvarying entity, just as he is likely to think that a dollar is of unchanging value. In fact the actual content of laws changes even as the purchasing power of the dollar shrinks or increases. In laws which are stated in most absolute terms, there is a surprising degree of elasticity. The requirement that no person shall be deprived of life, liberty, or property without due process of law is couched in the phraseology of natural rights, yet every generation has different conceptions as to what process is due process and what is meant by "life, liberty, and property." Even the meaning of a clear and unambiguous statute changes with subtle changes in dictionary interpretations of word connotations despite conscious attempts on the part of the law to preserve the original sense of the statute. Precedents which are clearly contradictory to the spirit of the times are whittled away by a minute search for technical reasons for distinguishing them from the class of cases to which they really belong. 
The presumptions of law are invented in favor of change, and these presumptions are likewise an insuperable handicap to an old precedent where the evidence of witnesses cannot be obtained. There are remarkable differences between the size of the bundle of rights conferred by a liberal construction of a statute compared with the size of the bundle of rights conferred by a strict construction of the same statute. Judges are instructed by the theory of the common law to construe liberally statutes in favor of common usage, and to construe strictly statutes in derogation of that common usage. Thus a change in face of the average standards of the community is resisted to the uttermost, while a statute designed to bring the common law in line with the development of community standards is aided in every possible way. There is also a growing tendency in the common law to limit the field of absolute rights whose content is not supposed to vary from one generation to another and to bring new cases that arise out of new relationships within the scope of relative rights and privileges.

If the most absolute laws are thus subject to subtle change, what can be expected of laws which expressly adopt the community standard, such as laws depending upon "reasonable care," "equity and good conscience," and "the prudence an ordinary, reasonable man would exercise under the same circumstances"? What is to be said of laws that are so indefinitely stated that the courts can select the interpretation that most nearly accords with the community standard that happens to prevail at the time? A statute which the court said could be interpreted by a hundred different judges in a hundred different ways ${ }^{\mathrm{x}}$ could surely be made to fit the exigencies of any social situation. What, moreover, is to be said of the function of juries in directing the course of development of the common law? When the counsel can submit barely enough legal evidence to get his case before the jury, the case will then be decided according to the jury's notion of who should get the verdict, sometimes with scant respect to the judge's instructions on the law. Thus there is opportunity for reading into the practical administration of justice many of the community ideals that may be at variance with the common law or the written statutory law.

${ }^{x}$ Whitney v. Turley (1842) (Dallas, Texas), p. 453. 
The unwritten law not only plays a rôle in the present evaluation of conduct outside of the courts, but it has a tendency to shape the course of future cases and future statutes.

Thus in the very process of internal change the common law maintains the outward show of uniformity and absoluteness. Judges will not admit that the law has changed; new conditions merely enforced fresh applications of old rules. Trial without a jury may be due process at one place or time, while it is an indispensable requisite under different conditions. A landowner has a right to pure air, but the "pure air" of a factory town would have been an intolerable nuisance when that same community was a frontier town. In other cases a pretense of following the law is made camouflage for acts departing from it. Only a lawyer can appreciate the nicety of the distinction between saying in one breath that no action to transfer title to land in Ireland can ever be maintained in England, and saying in the next breath that a court in England exercising equitable powers can nevertheless compel an Irish landowner temporarily residing in England to transfer title to his land at the order of the English court. ${ }^{x}$ The legal reason is that the one is an action in rem, which can be maintained only by a court having jurisdiction of the thing, the land in this case, and the other is an action in personam, which can be maintained by a court having jurisdiction of the person of the owner. Such distinctions mean little to the layman, for it is a contradiction in terms to say that a man has an absolute right of property, but that he can be compelled to give it up. Such is the method by which the common law has worked around the harshness of following absolute principles when the balance of convenience turned against their unrestricted use.

There is a vital difference between the internal evolution of the common law and a violent revolution by statutory change which breaks down settled rules with such gusto that the whole community is aware of the change. The one process is peaceful; it does not arouse animosities nor rub salt in the wounds it inflicts; and herein lies its great virtue from an economic standpoint. Quiet

${ }^{\mathrm{r}}$ Carteret v. Petty, 2 Swanston 323, Note (a) (1675); Ames Cases in Equity Jurisdiction, p. $2 \mathrm{r}$. 
change within the common law itself does not disturb public confidence in the mechanism of credit to any great extent; it does not give rise to vague apprehensions of greater damage to property and contract rights than it has actually inflicted, and hence does not increase the element of risk and lessen the degree of specialization any more than could have been helped. The secret of the success of securing a change in the common law without open show of force lies in the very fundamental facts that we have previously considered, namely, that stable laws perform their economic functions mainly through their influence upon the psychology of men. It is not so much the actual loss of property rights through changing laws that is to be deplored as the inhibition of habits of thrift, industry, and initiative that results from such a loss. By covering up or concealing the amount of the actual loss of property the bad after-effects can be reduced to the minimum. In doing this no great wrong is committed, for the loss of vested rights is after all largely a psychological matter, and the hardship to the individual is chiefly registered in the shock to settled habits of living or in the sense of deprivation. If the old rules are quietly or gradually changed, much of this sense of loss is alleviated, if not altogether prevented. Time is allowed for the adjustment to the new state of things. Furthermore, as a matter of making progressive ideals a practical success, this touch of diplomacy is of great importance. Communities are made up of conservatives as well as radicals, sometimes in fairly equal proportions, and it is not easily possible to secure a law which openly flies in the face of the traditions, habits, and prejudices of any substantial minority.

A policy of encouraging subtle changes in laws may be condemned as Machiavellian and as a secret and insidious plot which would strike every honest man with the terror of the silent sapping away of his resources. Some may think it has the objections of legislative jokers, the German spy system, and sabotage all rolled into one. The process of the growth of the common law is not so diabolical, however, because the change is neither made by nor for the benefit of any autocracy, but is made by the masses for their own benefit. It is simply a question of accomplishing very necessary changes in the least harmful way. It is the necessary com- 
promise that will retain as many of the economic benefits of the common law as possible without sacrificing the legitimate interests that are being hurt by that common law. Some vested rights must go down in order that the rights of the working classes may be uplifted, but in the process of reform we should take the greatest care not to destroy any more property than is absolutely necessary.

The apparent contradiction between the common law as an absolute standard that never changes and law as an ever-changing factor can be thus explained. The ideal of the common law is to adjust itself exactly to the habits and customs of the people. As a function of the whole variable content of the life of society to which it is applied it is immutable. The common law which moves exactly in proportion to the movement of everything around it does not seem to move at all. On the other hand, as an expression of the actual physical values the common law confers upon individuals the common law is variable. This variable quality is not appreciated, however, if the common law attains its goal of establishing a complete identity between the life of a people and the laws of a people.

If the common law thus tends to bring itself in line with the life of each period by a natural process of internal growth, why is external legislative pressure necessary? The reason lies in the fact that the customs of the common law tend to be perpetuated long after the reason for the development of the custom has passed. In the course of time the development of new and contradictory customs will force an abandonment of the ancient precedents. The people, however, must wait for a change in the dominant will before the changed standards of the people will be enacted into law. They must usually wait even longer, and hence comes the explanation of the existence of a law even after it conflicts with the desires of a dominant class. The people must wait for deliverance from the control of unpopular laws until the conservative members of the judiciary have been replaced by a generation of lawyers impregnated with the ideas of the new age, and by that time another organic change in the character of society may have occurred. Thus the growth of law follows a cycle. After receiving a dominant trend from the life of one age it tends to preserve those 
standards until they vary enough from the life of a period to force a reaction that will result in the re-formulation of legal premises. This was the case when the common law was successively transformed by the law merchant and the system of equity jurisprudence. ${ }^{x}$ Of course the whole system of law is not made over all at once; some of the archaic elements still survive, as they do in other social institutions, but the law is continually growing by the atrophy of obsolescent members and by the transfusion of new blood.

Legislation is a short cut to these natural processes of the common law. The very effect of the announcement of a new law cannot itself change the dominant habits of the people, but it can hasten the crystallization of that dominant attitude. A statute can open up a line of communication between the common law and the current needs of a period after the natural channels have been closed by an accumulation of precedent. The common law, if left to itself, might ultimately have worked out a theory of workingman's compensation that would have been more just to labor than the existing doctrine of employers' liability, but statutes have shortened the waiting period for such a theory by many years. If legislators were scientists or if they were composed of committees of experts in various fields of applied learning, they might pass laws which would incorporate the benefits of new discoveries into the legal system as soon as the inventor's test tubes had cooled. ${ }^{2}$ For such an advanced type of legislation, however, we must wait for the millennium.

In summary, then, the dangers of legislation consist in its willingness to follow any temporary movement. A multiplication of statutes destroys much of the advantage of certainty and stability in law. Due to lack of careful consideration of the whole social situation, it also vastly increases the possibility of error. The common law errs on the side of being too cautious for fear of taking a wrong step; the statutory law errs on the side of being too willing to jump to a conclusion without surveying all sides of the problem. The statutory law is more likely to be swayed by the caprice

× Cf. Roscoe Pound, "Social Problems and the Courts," American Journal of Sociology, XVIII (I9I 2), 33I-4I.

${ }^{2}$ Supra, p. 174 . 
of the moment, to be controlled by narrow interests for personal gain, to enact every fad and fashion into law, and to allow a swapping of personal favors at the expense of the general welfare. In short, the statute law has most of the vices and virtues exhibited by the opponents of custom in their attack upon the common law. The common law is more likely to follow a formal rule after the reasons for its adoption have passed, to allow vested interests to reap a social income after their function has disappeared, to repudiate new movements as transient because they conflict with fundamental principles, and to enforce a standard of morality from which this age has departed. Neither common law nor statute law, however, is true to type. It is no more a fact that common law is absolutely static than it is that statute law is absolutely dynamic. The one can no more resist change than the other can resist the force of old institutions in shaping a new policy. It is the problem of the statesman and the legislator to steer the happy course between the conservative common law and the radical statute law. Since the common law is the repository of the legal experience of the race, it has sifted out some elemental traits of human nature that have remained the same from the dark ages to the world-war. These stable standards of the past furnish us a partial guide to the future, because by drawing a line through the milestones of the past we can plot a curve which may be projected into the coming century. This line will not furnish the exact route of our progress, but it will indicate a general direction of travel from which we cannot deviate far without disturbing fundamental forces that will start a retrograde movement. If changes in law are confined to the limits established by the experience table of the common law, modified by the more fundamental changes that occur from time to time, vested rights of property will not be confiscated by the operation of the legal system to any appreciable extent, and the fundamental bases of economic relationships will not be unnecessarily jolted. Although such development may be slow, it will not be followed by the backsliding that succeeds more rapid progress.

Beloit College

HOMER Hoyt 